\title{
News Frames of Israeli Settlement in the American Newspapers' Websites
}

\author{
Dr. Talat A. H. Issa ${ }^{1^{*}}$, Mr. Abdulla M. Al Hamarna ${ }^{2}$ \\ ${ }^{I}$ Associate Professor of Journalism, Islamic University of Gaza \\ ${ }^{2}$ Researcher in Israeli settlement, Gaza-Palestine
}

*Corresponding Author: Dr. Talat A. H. Issa, Associate Professor of Journalism, Islamic University of Gaza

\begin{abstract}
This study aims to identify the most important news frames for the issue of Israeli settlement in the websites of American newspapers, and to know the topics of Israeli settlement, which focused on these websites, the most prominent framing mechanisms used and tools, and to reveal the attributes and trends of news frames and trends, and the most important key figures, the frames of the reasons and results.

This study belongs to descriptive researches using content analysison a selected news in the websites of the New York Times and the Washington Post from January 1st, 2015, to December 31th, 2017, there were 365 news about Israeli settlement in the two websites, , 175 in the New York Times \& 190 in the Washington Post,

The study found that the frames of the expected results got the first rank of the news frames of the Israeli settlement issue in the websites of the study, then the frames of responsibility, and finally the frames of the proposed solutions, and the Israeli key figures outnumbered the International \& Palestinian key figures in the websites of the study and this shows the weakness of the Palestinian presence in this vital issue.
\end{abstract}

Keywords: News Frames - Israeli Settlements - West Bank - Websites of American newspapers.

\section{INTRODUCTION}

The settlement issue is one of the most important tools which Israel implemented the policy of displacement that expelled the Palestinians from their lands since 1948. Israel built the "kibbutzim" that was deported to the final status negotiations, along with Jerusalem, refugees, water and borders according to the 1993 Oslo Declaration of Principles. After Oslo, the Israeli government confiscated 36,000 dunams in and around Jerusalem. The 1998 Wye River Agreement stated that no action would be taken to change West Bank and Gaza Strip status, but in 1999, more than 27 outposts were established.

Israeli settlement has become a media material circulated in the American media, and the world witnessed in the late last century a major revolution in communications led to a major shift in the role of the media, and the extent of the world's reliance on it to pass its political, economic and social programs, and therefore "media and diplomacy has became Two sides of the same coin: foreign policy and the image of the state in the international and regional communities ${ }^{(1)}$ "

The Western media views the Palestinian issue as a conflict between two parties, and its media materials are completely devoid of the historical context of the Palestinian cause. It even deals with the coverage of Israeli aggressions in its wars on an equal footing, and intentionally recounts the details of the Israeli deaths, while our martyrs are figures in their media without any details ${ }^{(2)}$.

On the other hand, the influence of the media in American foreign policy comes from the strength of the Israelis lobby and its control over the American media, so that the media often represents the will of that lobby.

\footnotetext{
${ }^{1}$ Faqih, contemporary Arab media. (website)

${ }^{2}$ Shaheen, the role of the media towards the Palestinian cause and mechanisms to promote global media solidarity with the Palestinian people. (website)
} 
Israeli settlement issue is one of the most fundamental issues related to the Palestinian-Israeli conflict that is dealt with in the American media, these mass media through dealing with such issues are biased by looking at them from the perspective of American interest, they adopt a kind of selectivity through automatic sorting of news and events, so what is consistent with the general policy of the State becomes news, and became a fact, and what violates foreign policy orientations becomes evidence that the opponent is a threat to the supreme national interest, which requires confrontation ${ }^{(3)}$.

\section{LITERATURE REVIEW}

Number of studies have addressed this issue, including Al Zahar study (2018) ${ }^{(4)}$, which found the prevalence of the anti-settlement trend in American electronic newspaper articles, the study of Al-Ajla $(2015)^{(5)}$ confirmed the significant decrease in the presence of Arab actors in the speech of Palestinian newspapers, which indicates the weakness of the actual Arab role towards the issue of Israeli settlements, the study of Al-Ajla (2014) ${ }^{(6)}$ referred that the conflict frames came first in the media frames of Settlements' topics, followed by the responsibility frames, then the moral frames.

Qutob study $(2011)^{(7)}$ proved that illegal settlements in the West Bank were established with a deliberate plan to create facts on the ground. It harms the "peace negotiations," Amer \& Amer study $(2011)^{(8)}$ confirmed that American newspapers presented Israeli settlement activities in occupied Jerusalem and the West Bank as detrimental to the "peace negotiations", while Hughes study $(2011)^{(9)}$ found that the goal of building the separation barrier in the West Bank is not security; it seeks to annex settlements, and control land and natural resources.

\section{STUdy Problem}

The problem of this study is to identify the news frames of the Israeli settlement issue in the websites of American newspapers, by identification of the topics of Israeli settlement, and the news frames of this issue, and the mechanisms\& tools of framing used, and the most important key figures.

\subsection{Study Objectives and Questions}

This study aimed to find out how the websites of American newspapers frame the issue of Israeli settlement. A number of questions have been drawn to achieve this aim:

- How interested are the websites of American newspapers on the issue of Israeli settlement? What are the topics of settlement?

- What are the sources on which the websites of American newspapers relied on the Issue of the Israeli settlement? What are the news forms of this issue?

- What are the news frames of the issue of Israeli settlement in the websites of American newspapers (conflict - reactions - responsibility - humanitarian concerns)?

- What are the frames of causes, solutions and results of the Israeli settlement issue raised by the websites of American newspapers?

- What are the key figures on which the websites of American newspapers focused on in addressing the issue of Israeli settlement? What are the mechanisms of framing?

\subsection{Theoretical Framework}

The study uses media frames theory, and to clarify the concept of framing, there are "three explicit terms denoting framing: Framing is a process of mass communication of the multilateral, frames

\footnotetext{
${ }^{3}$ Ibid

${ }^{4}$ Al-Zahar, Trends of Opinion Articles in American Electronic Newspapers Towards Settlement in Palestine: A Comparative Analytical Study.

${ }^{5}$ Al-Ajla, Mohammed, Palestinian Discourse Towards the Israeli Settlement Issue in the West Bank: A Comparative Analytical Study.

${ }^{6}$ Al-Ajla, Rami, Discourse Towards the Issue of Jerusalem in International Arab Newspapers: A Comparative Analytical Study.

${ }^{7}$ Qutob, An Analysis of Israel's Settlement Policy in the Occupied West Bank after the Six-Day War and its Impact on the Peace-Process (1967-2002).

${ }^{8}$ Amer and Amer, U.S. Media Coverage of the Situation in Jerusalem: A Discourse Analysis Study.

${ }^{9}$ Hughes, Territoriality, Sovereignty and the Nation-state System in Israel-Palestine: The Creation of the Palestinian Bantustan "state" and Shifting Palestinian Resistance Tactics
} 
refers to the angles which cover events, topics and different issues, some consider this term to be a kind of scientific shortcoming, because it reduces the framing process and empties it from its content, this concept does not accurately reflect the meaning of the framing process ${ }^{(10)}$.

Robert Entman defined the media frames as "a deliberate selection of certain dimensions of the event, or issue, and making it more prominent in the media text in a way that regulates, identifies, and harmonizes the issue" ${ }^{(11)}$.

\section{MeThodology}

This study is based on the survey methodology, which is consider a scientific effort to obtain data and information about a phenomenon ${ }^{(12)}$. The study uses a content analysis to describe the news content of the Israeli settlement issue in the websites of American newspapers. The content analysis included category of topics, news source, news frames, reason and solution frames, results frames, key figures and framing mechanisms.

\subsection{The Sample}

The researchers chose the websites of the New York Times and the Washington Post newspapers as a sample of the study because they have record numbers of browser numbers, and therefore they are effective and influential sites, and because of their interest on the issue of Israeli settlement in the Palestinian territories. The researchers chose three years between (Jan $1^{\text {st }} 2015$ to Dec $\left.31^{\text {st }} 2017\right)$ to be studied, because this period witnessed an escalation of Israeli settlement activity in the occupied territories in light of the stalled peace process and important decisions against the settlements.

The researchers have limited all the news topics related to the issue of Israeli settlement in this period by advanced search method in the two websites, and by searching the keywords as: Israeli Settlement, Settlers, Land Confiscation, Separation Wall, Settlements, Jewish Settlement.

\section{RESUlts}

The researchers deal with the results of the study of content analysis and analysis of news frames, then discussing and explaining them, and comparing them with previous studies.

\subsection{Israeli Settlement Topics}

Table1: Order of Israeli Settlement topics

\begin{tabular}{|c|c|c|c|c|c|c|}
\hline \multirow{2}{*}{ Topics } & \multicolumn{2}{|l|}{ NT } & \multicolumn{2}{|c|}{ The Washington Post } & \multicolumn{2}{|c|}{ Total } \\
\hline & $\mathbf{F}$ & $\%$ & $\mathbf{F}$ & $\%$ & $\mathbf{F}$ & $\%$ \\
\hline Settlements Legitimacy & 85 & 22.5 & 122 & 28.8 & 208 & 26 \\
\hline US administrations Attitudes & 72 & 19 & 103 & 24.3 & 175 & 21.9 \\
\hline Land confiscation & 73 & 19.4 & 100 & 23.7 & 173 & 21.7 \\
\hline Settlements establishment & 40 & 10.6 & 23 & 5.4 & 63 & 7.9 \\
\hline Int'l Attitudes at Settlement & 42 & 11.1 & 16 & 3.8 & 57 & 7.1 \\
\hline Operations against settlers & 22 & 5.8 & 20 & 4.8 & 42 & 5.2 \\
\hline Settlers' violations & 13 & 3.4 & 14 & 3.3 & 27 & 3.3 \\
\hline Settlements evacuation & 11 & 2.9 & 6 & 1.4 & 17 & 2.1 \\
\hline Boycott settlement products & 1 & 0.3 & 13 & 3 & 14 & 1.7 \\
\hline Obstructing the peace process & 3 & 0.8 & - & - & 3 & 0.3 \\
\hline US support for settlement & - & - & 3 & 0.7 & 3 & 0.3 \\
\hline Other & 15 & 4 & 3 & 0.7 & 18 & 2.2 \\
\hline Total & 377 & 100 & 423 & 100 & 800 & 100 \\
\hline
\end{tabular}

The researchers conclude from the previous results that the study websites focused on illegality of Israeli settlements frames in line with the positions of the American administrations, as well as international positions from it, so the study websites did not focus on some other settlement issues as shown in previous results, which explains their editorial policy in line with this trend.

\footnotetext{
${ }^{10}$ Arowolo, Understanding Framing theory, PP (3).

${ }^{11}$ Entman, Framing Towards Clarification of a Fractured Paradigm, p (52).

${ }^{12}$ Entman, Framing Towards Clarification of a Fractured Paradigm, p (52)
} 
The study of (Amer, 2008) proved that the New York Times omitted important topics, and focused on topics that do not affect the interests of Israel ${ }^{(13)}$, and that shows the study websites' reliance on this approach in dealing with the issue of Israeli settlement, and the study of (Qutob, 2011) confirmed that Israel damaged from the policy of settlement, this policy contributed in isolating itself, which showed the issue of illegal Israeli settlements in the first place in the study websites as a result of the adoption of a world position against this policy, even the allies of Israel Like France, United kingdom, United States of America have expressed their opposition to settlement policy ${ }^{(14)}$.

The researchers conclude that the issue of land confiscating on got a high rate of settlement topics in the study websites is an optimal exploitation of the Israeli government for legal loopholes that consider the West Bank as disputed land, and does not belong to the Palestinians, and that the future of these lands will be decided in the final solution negotiations. The researchers assert that a large number of reports considered the lands of the West Bankas disputed ones, and the Washington Post reported a report confirming that the West Bank lands are disputed ${ }^{(15)}$.

The study of (Hughes, 2011) showed that Israeli settlement expansion in the West Bank aims to confiscate Palestinian lands in favor of expanding the Israeli settlement. Hughes added that the goal of building the separation wall - one of the tools of Israeli settlement in the West Bank - is not security, but seeks to annex settlements and increase control of land in order to control natural and vital resources ${ }^{(16)}$.

The study of (Abadjiev, 2015) confirmed that the low cost of Israeli settlements in the West Bank encourages its continuation, also the study confirmed that Israeli local investment has helped increase land confiscation ${ }^{(17)}$, the researchers through reports in the websites of study that Israel has enacted laws to facilitate the confiscation of land under the cloak of Israeli law, the study of (Al-Jadba, 2011) confirmed that the goal of the existence of Israeli settlements in the West Bank is to control the Palestinian territories and expel the indigenous people there ${ }^{(18)}$.

The researchers consideredthat the websites of study dealt with the subject of operations against settlers more than the settlers attacks against the Palestinians, which is biased in favor of the Israeli occupation, where the news reports in the websites of study focused on the humanizing the settlers who were subjected to Palestinian attacks, while the perpetrators of the attacks are often described as murderers and criminals ${ }^{(19)}$.

The high rates of obstructing the peace process issue indicates the weakness of the websites of the study's interest in the peace process, this is a reflection of the American political apathy towards the solution of the Palestinian-Israeli conflict. The researchers noted that some of the reports in the websites of study were about US procedures that prevent the boycott of Israel on cultural and economic level, a Washington Post report confirms that some states have enacted laws criminalizing boycotts of Israel.

\subsection{News Source}

Table2: Source of the Israeli Settlement Issue news

\begin{tabular}{|c|c|c|c|c|c|c|}
\hline \hline \multirow{2}{*}{ Websites } & \multicolumn{2}{|c|}{ NT } & \multicolumn{2}{|c|}{ WP } & \multicolumn{2}{c|}{ Total } \\
\cline { 2 - 7 } & $\mathrm{F}$ & $\%$ & $\mathrm{~F}$ & $\%$ & $\mathrm{~F}$ & $\%$ \\
\hline Reporter & 175 & 100 & 190 & 100 & 365 & 100 \\
\hline
\end{tabular}

The researchers conclude that the reliance of the website of study significantly on the reporter reflected the nature of news coverage, as a result, the websites of the study relied on Israeli sources

\footnotetext{
${ }^{13}$ Amer, The linguistics of representation: the New York Times' discourse on the second Palestinian Intifada

${ }^{14}$ Qutob, An Analysis of Israel's Settlement Policy in the Occupied West Bank after the Six-Day War and its Impact on the Peace-Process (1967-2002).

${ }^{15}$ The Washington Post, Palestinians attack inside settlements, Israeli mother of 6 killed. (Website)

${ }^{16}$ Hughes, Territoriality, Sovereignty and the Nation-state System in Israel-Palestine: The Creation of the Palestinian Bantustan "state" and Shifting Palestinian Resistance Tactics.

${ }^{17}$ Abadjiev, The return to Judea and Samaria: Qualitative analysis on the dynamics of Israeli settlements in West Bank and East Jerusalem.

${ }^{18}$ Aljadba, Israeli Settlement in East Jerusalem 1967-2009: A Study in Geopolitics.

${ }^{19}$ The Washington Post, Netanyahu wants Palestinian violence linked to radical Islam. (Website)
} 
more than Palestinian sources, the conclude is in line with the study of (Aziz, 2014), which confirmed that the New York Times relied on Israeli sources more than relying on Palestinian sources to cover the news of Palestinian and Israeli deaths during the second Israeli invasion of Lebanon in $2006^{(20)}$.

It is worth mentioning that the correspondent of the New York Times - Isabel Kershner - is permanently resident in Israel, and although she adopts all Israeli terms, one of the Times of Israel writers strongly attacked her because she criticized in one of her reports the Israeli democratic and expected its demise, Accordingly, Alan Edelstein called on the public not to adopt the New York Times as a source of news about Israel; because it has one dimension in coverage ${ }^{(21)}$.

The New York Times website followed a more engaging approach with the reporter to write reports on Israeli settlements and news of Palestinian operations against Israeli settlements in the West Bank, such as Zia Hadid, who is of Palestinian descent, and participated along with more than one journalist in reporting settlements in the West Bank. Such as the report sheparticipated in its writing about the Israeli Foreign Ministry's disapproval of the EU's labeling of goods produced in settlements when exported to the $\mathrm{EU}^{(22)}$.

The Washington Post website relied on British-born Israeli journalist Ruth Eglash, who worked for the Jerusalem Post, as a writer specialized in international media, as well as the newspaper's chief of staff William Booth. Media reports said Ruth had married a supporter of Israeli policies in the US, the report said that Ruth had difficulties in providing fair and non-emotional coverage towards the Palestinians, especially since the newspaper refused to disclose whether Ruth Eglash had told her officials about her husband's pro-Israel attitudes as stipulated by the laws in the paper ${ }^{(23)}$. Ruth described herself in an article in Huffington Post with the Jordanian journalist Hani Huzaima as an Israeli citizen, in the same report, she spoke passionately about Israel and defend the values they represent Israel ${ }^{(24)}$.

\subsection{News Formats}

Table3: The format of the press article on the Israeli settlement issue

\begin{tabular}{|c|c|c|c|c|c|c|}
\hline \multirow{2}{*}{ Mebsites } & \multicolumn{2}{|c|}{ NT } & \multicolumn{2}{c|}{ WP } & \multicolumn{2}{c|}{ Total } \\
\cline { 2 - 7 } & F & \% & F & \% & F & 91 \\
\hline Reports & 151 & 88.3 & 181 & 95.3 & 332 & 9 \\
\hline News Articles & 24 & 11.7 & 9 & 4.7 & 33 & $\mathbf{1 0 0}$ \\
\hline Total & $\mathbf{1 7 5}$ & $\mathbf{1 0 0}$ & $\mathbf{1 9 0}$ & $\mathbf{1 0 0}$ & $\mathbf{3 6 5}$ & $\mathbf{1 0 0}$ \\
\hline
\end{tabular}

It is clear from this table that the reliance of the websites ofstudy on the news report in the media marketing of Israeli settlements is very consistent with the results of Table (2) that shows the press source of the Israeli settlement materials in the websites of the study, where the presence of one or more correspondent of the newspaper makes its dependence on the report. This finding is similar to the study of (Ross, 2003) and (Issa, 2016), which showed that US newspapers often focus on reports in covering updates, rather than reports that have some analysis ${ }^{(25)}$.

\subsection{Conflict Frames}

Table4: Conflict Frames in the Israeli Settlement issue

\begin{tabular}{|l|l|l|l|l|l|l|}
\hline \multirow{2}{*}{ Frames } & \multicolumn{2}{r|}{ Websites } & NT & WP & \multicolumn{2}{l|}{ Total } \\
\cline { 2 - 8 } & F & \% & F & $\%$ & F & $\%$ \\
\hline Confiscating Palestinian Lands & 93 & 56.7 & 109 & 55.9 & 202 & 56.3 \\
\hline Operations against Israeli settlers & 33 & 20.1 & 39 & 20 & 72 & 20 \\
\hline Military checkpoints near Settlements & 26 & 15.8 & 37 & 19 & 63 & 17.5 \\
\hline Settlers' attacks on Palestinian villages & 5 & 3 & 6 & 3 & 11 & 3 \\
\hline
\end{tabular}

\footnotetext{
${ }^{20}$ Aziz, An Analysis of Print Media Coverage of the Palestinian-Israeli Conflict During the Second Israeli Invasion of Lebanon in 2006

${ }^{21}$ Edelstein, Isabel Kershner, the NY times and the demise of our democracy. (Website)

${ }^{22}$ Hadid, Israeli Foreign Minister Denounces E.U. Proposal to Label Settlement Products. (Website)

${ }^{23}$ Abunimah, Washington Post's new Jerusalem correspondent married to pro-Israelpropagandist. (Website)

${ }^{24}$ Eglash: Hazaimeh, Why We Can't Write This Story. (Website)

${ }^{25}$ Issa, News frames of the Israeli aggression on Gaza 2014 in the website of the New York Times: an analytical study, pp (154).
} 


\begin{tabular}{|l|l|l|l|l|l|l|}
\hline Settlers' Violations & 5 & 3 & 1 & 0.5 & 6 & 1.7 \\
\hline Dismantling Settlements & - & - & 3 & 1.5 & 3 & 0.8 \\
\hline Confiscating Palestinian Lands & 2 & 1.2 & - & - & 2 & 0.5 \\
\hline Total & $\mathbf{1 6 4}$ & $\mathbf{1 0 0}$ & $\mathbf{1 9 5}$ & $\mathbf{1 0 0}$ & $\mathbf{3 5 9}$ & $\mathbf{1 0 0}$ \\
\hline
\end{tabular}

The high rates of Confiscating Palestinian Lands and Military checkpoints near Settlements' frames stands to reason, Israeli occupation forces and settlers are heavily present in Palestinian daily life, this is consistent with the study of (Cornett III, 2008), which confirmed that heavy Israeli repression in Palestinian daily life createda catastrophe and exacerbates the conflict ${ }^{(26)}$.

The researchers believe that the concordance of the results of this study with the results of the following studies explains why the frames of the dismantling of settlements get a low rates, one of the most important reasons is that Israel considered the settlement as an internal issue, and its unwillingness to export the dismantling as a solution to the settlement problem in the West Bank, this is consistent with the study of (Qutob, 2011), which reported that illegal settlements in the West Bank were part of a deliberate plan as a means of creating facts on the ground ${ }^{(27)}$, and also differed with the study of(Hughes, 2011), which reported that the creation of a Palestinian Bantustan state is an Israeli interest in order to maintain the demographic balance in favor of a Jewish state, the study also confirmed that Israeli policy shifted from the full annexation of West Bank to the policy of building the Palestinian Bantustan state ${ }^{(28)}$.

The arrangement of the conflict frames in the total coincided with the findings of the study of (Hoffman, 2010), which reported that the government has the ability to exert influence on the media on foreign policy ${ }^{(29)}$.

\subsection{Reaction Frames}

Table5: Frames of Reactions to the Israeli Settlement Issue

\begin{tabular}{|l|l|l|l|l|l|l|}
\hline \multirow{2}{*}{ Reactions } & \multicolumn{2}{l}{ Websites } & NT & WP & \multicolumn{2}{l|}{ Total } \\
\cline { 2 - 8 } & \multirow{2}{*}{$\mathbf{F}$} & $\mathbf{\%}$ & $\mathbf{F}$ & $\mathbf{\%}$ & $\mathbf{F}$ & $\mathbf{\%}$ \\
\hline Balanced & 63 & 48.5 & 93 & 55.3 & 156 & 52.3 \\
\hline Proponent & 45 & 34.6 & 43 & 25.6 & 88 & 29.5 \\
\hline Opposition & 22 & 16.9 & 32 & 19 & 54 & 18.1 \\
\hline Total & $\mathbf{1 3 0}$ & $\mathbf{1 0 0}$ & $\mathbf{1 6 8}$ & $\mathbf{1 0 0}$ & $\mathbf{2 9 8}$ & $\mathbf{1 0 0}$ \\
\hline
\end{tabular}

Although the rates of balanced reactions was higher than supportive frames, the supportive frames occupies a strong rates in the websites of the study which reflects the policy of those websites, and this result is consistent with the study (AbduIshaiba, 2013), which stated that US coverage of the conflict adopts double standards when judging Israel's practices, this coverage describes the Palestinian attacks as terrorist, while attacks by the Israeli occupation as part of legitimate reactions, the study also showed that the US media is biased in favor of Israel, which displays a false and distorted picture ${ }^{(30)}$.

The low rates of the anti-settlement reaction frames show a bias of the study's websites. This finding is consistent with the study of (Amer \& Amer, 2011) which reported that there is a constant tendency in press reports in the American media to select news styles, information and vocabulary that fit the Israeli justifications ${ }^{(31)}$.

\subsection{Frames of Responsible Parties}

Table6: Frames of the responsible parties for Israeli Settlement Issue

\begin{tabular}{|l|l|l|l|l|l|l|}
\hline \multirow{2}{*}{ Responsible Parties } & NT & WP & \multicolumn{2}{l|}{ Total } \\
\cline { 3 - 8 } & F & $\%$ & F & $\%$ & F & $\%$ \\
\hline Israeli Government & 163 & 72.4 & 189 & 69.2 & 352 & 65.2 \\
\hline
\end{tabular}

${ }^{26}$ Cornett III,Israeli West Bank Settlements: Perversion of Realism and Obstacle to Peace

${ }^{27}$ Qutob, An Analysis of Israel's Settlement Policy in the Occupied West Bank after the Six-Day War and its Impact on the Peace-Process (1967-2002).

${ }^{28}$ Hughes, Territoriality, Sovereignty and the Nation-state System in Israel-Palestine: The Creation of the Palestinian Bantustan "state" and Shifting Palestinian Resistance Tactics

${ }^{29}$ Hoffman, Framing Hamas: A Case Study of U.S. Foreign Policy \& Media Coverage.

${ }^{30}$ Abuishaiba, The American Media Coverage of the Israel-Palestine Conflict (2010-2012).

${ }^{31}$ Amer \& Amer, U. S. Media coverage of the situation in Jerusalem: A Discourse Analysis Study.

International Journal of Media, Journalism and Mass Communications (IJMJMC) Page| 6 


\begin{tabular}{|l|l|l|l|l|l|l|}
\hline American Government & 50 & 22.2 & 75 & 27.5 & 125 & 25.1 \\
\hline Israeli Settlers & 4 & 1.8 & 2 & 0.7 & 6 & 1.2 \\
\hline Israeli Parties & 5 & 2.2 & - & - & 5 & 1 \\
\hline Israeli Army & 1 & 0.4 & 2 & 0.7 & 3 & 0.6 \\
\hline Other & 2 & 0.9 & 5 & 1.8 & 7 & 1.4 \\
\hline Total & $\mathbf{2 2 5}$ & $\mathbf{1 0 0}$ & $\mathbf{2 7 3}$ & $\mathbf{1 0 0}$ & $\mathbf{4 9 8}$ & $\mathbf{1 0 0}$ \\
\hline
\end{tabular}

The analysis of the websites of the study show that the Israeli government is primarily responsible for the Israeli settlements, and this is very much in line with the official position of the administrations of Presidents Barack Obama and Donald Trump. But the Washington Post website held the US administration more responsible for settlements than the New York Times. The Washington Post website conducts a more critical editorial policy of US policies on the Israeli settlement issue.

However, there was some contradiction in the official positions of the Trump administration. At the beginning of his reign, he expressed his disagreement with the idea that settlements impede the peace process. This contrasts with the study of (Amer \& Amer, 2001) where journalists in the New York Times and The Washington Post presented Israeli settlement activities in occupied Jerusalem and the West Bank as detrimental peace negotiations between Israelis and Palestinians ${ }^{(32)}$.

\subsection{Humanitarian Frames}

Table7: Humanitarian Frames for the Israeli Settlement Issue

\begin{tabular}{|l|l|l|l|l|l|l|}
\hline \multirow{2}{*}{ Humanitarian Frames } & NT & WP & \multicolumn{2}{l|}{ Total } \\
\cline { 3 - 8 } & \multirow{2}{*}{ Febsites } & $\mathbf{\%}$ & $\mathbf{F}$ & $\mathbf{\%}$ & $\mathbf{F}$ & $\mathbf{\%}$ \\
\hline Israeli concerns & 44 & 71 & 27 & 60 & 71 & 66.3 \\
\hline Palestinian concerns & 18 & 29 & 18 & 40 & 36 & 33.6 \\
\hline Total & $\mathbf{6 2}$ & $\mathbf{1 0 0}$ & $\mathbf{4 5}$ & $\mathbf{1 0 0}$ & $\mathbf{1 0 7}$ & $\mathbf{1 0 0}$ \\
\hline
\end{tabular}

The researchers believe that the high rates of Israeli humanitarian concerns in the website of the study indicates their clear adoption of the Israeli narrative, but the most important is that the websites of the study show this narrative in a human context, this consistent with results of table (1), in which the subject of operations against settlers received a high rate, which led the websites of the study to focus on Israeli humanitarian concerns. This finding contrasts with the study of (Issa, 2016) which stated that the New York Times website focused on the frames of Palestinian humanitarian concerns more than Israeli humanitarian concerns ${ }^{(33)}$.

This finding is consistent with the findings of the study of (Ross,2003), which proved that the New York Times portrayed Palestinians as terrorist \&criminals undermining calm during the attacks of September $11,2001^{(34)}$.

\subsection{Frames of Reasons}

Table8: Frames of the Reasons for Israeli Settlement

\begin{tabular}{|c|c|c|c|c|c|c|}
\hline \multirow[t]{2}{*}{ Websites } & \multicolumn{2}{|l|}{ NT } & \multicolumn{2}{|c|}{ The Washington Post } & \multicolumn{2}{|c|}{ Total } \\
\hline & $\mathbf{F}$ & $\%$ & $\mathbf{F}$ & $\%$ & $\mathbf{F}$ & $\%$ \\
\hline Controlling Lands & 84 & 47 & 107 & 60.8 & 191 & 53.8 \\
\hline Israeli Political Motivations & 49 & 27.4 & 28 & 15.9 & 77 & 21.7 \\
\hline Israeli Security Motivations & 15 & 8.4 & 10 & 5.7 & 25 & 7 \\
\hline Religion Motivations & 10 & 5.6 & 9 & 5.1 & 19 & 5.3 \\
\hline American Support & 4 & 2.2 & 12 & 6.8 & 16 & 4.5 \\
\hline Economic Reasons & 4 & 2.2 & 10 & 5.7 & 14 & 3.9 \\
\hline Responding to Security council decisions & 5 & 2.8 & - & - & 5 & 1.4 \\
\hline Other & 8 & 4.4 & - & - & 8 & 2.2 \\
\hline Total & 179 & 100 & 176 & 100 & 355 & 100 \\
\hline
\end{tabular}

\footnotetext{
${ }^{32}$ Amer and Amer, U.S. Media Coverage of the Situation in Jerusalem: A Discourse Analysis Study.

${ }^{33}$ Ibid, pp (159).

${ }^{34}$ Ross, Framing of the Palestinian/Israeli conflict in thirteen months of New York Times editorials surrounding the attacks of Sept. 11, 2001, (p 4).
} 
The results refers to the fact that the frames of controlling Lands\&Israeli Political Motivations have the highest rates gives a clear indication of the features of Israeli public policy towards the West Bank, and this is consistent with the results of the study of (Qutob, 2011), which proved that illegal settlements were created in the West Bank under a well-thought-out plan to create facts on the ground $^{(35)}$, and this also coincided with the study of (Hughes, 2011) which stated that Israeli policy had shifted from a policy of full annexation of West Bank land to a policy of establishing a Palestinian Bantustans state ${ }^{(36)}$.

The researchers' analysis of news materials at the websites of the study shows that US support for Israeli settlement in the West Bank was very clear after Trump took office in early 2017, a report in the Washington Post stated that Trump donated to a university in an Israeli settlement with $10,000 \$^{(37)}$, this gives strength to the current supporting the Israeli settlement in the United States.

\subsection{Solutions Frames}

Table9: Solutions Frames of the Israeli Settlement Issue

\begin{tabular}{|c|c|c|c|c|c|c|}
\hline \multirow{2}{*}{$\mathrm{P}_{\text {Solutions Frames }}^{\text {Websites }}$} & \multicolumn{2}{|l|}{ NT } & \multicolumn{2}{|l|}{ WP } & \multicolumn{2}{|c|}{ Total } \\
\hline & $\mathbf{F}$ & $\%$ & $\mathbf{F}$ & $\%$ & $\mathbf{F}$ & $\%$ \\
\hline Two-state solution & 77 & 38.7 & 113 & 50.9 & 190 & 45.1 \\
\hline Political pressure & 79 & 39.7 & 69 & 31 & 148 & 35.1 \\
\hline Boycott settlement products & 5 & 2.5 & 13 & 5.8 & 18 & 4.3 \\
\hline UN resolutions & 10 & 5 & 4 & 1.8 & 14 & 3.3 \\
\hline Implementation of int'l laws & 5 & 2.5 & 8 & 3.6 & 13 & 3 \\
\hline Stop building new settlements & 4 & 2 & 3 & 1.3 & 7 & 1.7 \\
\hline One state & 2 & 1 & 5 & 2.2 & 7 & 1.7 \\
\hline Resumption of the peace process & 4 & 2 & 1 & 0.4 & 5 & 1.2 \\
\hline Lawsuits & 5 & 2.5 & - & - & 5 & 1.2 \\
\hline Land exchange & 1 & 0.5 & - & - & 1 & 0.2 \\
\hline Other & 7 & 3.5 & 6 & 2.7 & 13 & 3 \\
\hline Total & 199 & 100 & 222 & 100 & 421 & 100 \\
\hline
\end{tabular}

The researchers believe that the frames of the resumption of the peace process, legal claims, and land exchange have got low duplicates in the the Websites of the study, this was consistent with the results of Table (6), where the parties responsible for the Israeli settlement process are the Israeli government and the US administrations, thus the solutions that have obtained low rates is not a priority for these parties, this is consistent with the study of (Cornett III, 2008), which concluded that Israel refuses to reach a solution to the problem of Israeli settlements in the West Bank, thus exacerbating the threat posed by its Arab neighbors ${ }^{(38)}$.

The results of Table (8) indicate that the possession of the frames of the two-state solution at the highest percentage in the Websites of the study constitutes an international consensus to resolve the issue of Israeli settlement, which is one of the keys to the political solution to the Palestinian-Israeli conflict. Israel didn't respond to the political pressure exerted by the countries of the world to stop Israeli settlements.

\subsection{Frames of Results}

Table10: Frames of Results for Israeli Settlements issue

\begin{tabular}{|l|l|l|l|l|l|l|}
\hline \multirow{4}{*}{ Wesults Frames } & Websites & NT & WP & \multicolumn{2}{l|}{ Total } \\
\cline { 2 - 8 } & \multirow{2}{*}{} & $\mathbf{F}$ & $\mathbf{F}$ & $\mathbf{\%}$ & $\mathbf{F}$ & $\mathbf{\%}$ \\
\hline Palestinian land Confiscation & & & & & & \\
\hline Two-state solution fall & 82 & 25.9 & 105 & 29.2 & 187 & 27.7 \\
\hline
\end{tabular}

\footnotetext{
${ }^{35}$ Qutob, An Analysis of Israel's Settlement Policy in the Occupied West Bank after the Six-Day War and its Impact on the Peace-Process (1967-2002).

${ }^{36}$ Hughes, Territoriality, Sovereignty and the Nation-state System in Israel-Palestine: The Creation of the Palestinian Bantustan "state" and Shifting Palestinian Resistance Tactics.

${ }^{37}$ The Washington Post, Trump once donated $10000 \$$ to a West Bank Israeli Settlement. (Website)

${ }^{38}$ Cornett III,Israeli West Bank Settlements: Perversion of Realism and Obstacle to Peace.
} 


\begin{tabular}{|l|l|l|l|l|l|l|}
\hline \multicolumn{9}{|l}{} \\
\hline Imposing a fait accompli & 57 & 18 & 53 & 14.8 & 110 & 16.3 \\
\hline Attacks on Palestinian civilians & 29 & 9.1 & 52 & 14.5 & 81 & 12 \\
\hline Disrupt negotiations & 42 & 13.2 & 10 & 2.8 & 52 & 7.6 \\
\hline Collective punishment on Palestinians & 16 & 5 & 15 & 4.2 & 31 & 4.6 \\
\hline Palestinian Physical losses & 7 & 2.2 & 9 & 2.5 & 16 & 2.4 \\
\hline Disruption of peace process & 9 & 2.8 & 4 & 1.1 & 13 & 2 \\
\hline Violations of int'l law & 6 & 1.9 & 4 & 1.1 & 10 & 1.5 \\
\hline Israeli security control & 4 & 1.3 & 4 & 1.1 & 8 & 1.1 \\
\hline Other & 5 & 1.6 & 4 & 1.1 & 9 & 1.3 \\
\hline Total & $\mathbf{3 1 7}$ & $\mathbf{1 0 0}$ & $\mathbf{3 5 9}$ & $\mathbf{1 0 0}$ & $\mathbf{6 7 6}$ & $\mathbf{1 0 0}$ \\
\hline
\end{tabular}

It is clear from the previous table that the possession of the confiscation of Palestinian land as the highest result of Israeli settlement was consistent with the results of tables (6) \& (10), where the confiscation frames of the Palestinian territories comes first, as well as consistent with the results of table (2) where the issue of land confiscation came third in the ranking of Israeli settlement issues. This is in line with (Hughes, 2011), which states that Israeli policy has shifted from a policy of full annexation of West Bank land to a policy of establishment Palestinian Bantustans state ${ }^{(39)}$.

It was found that the frames of the abuse of Palestinian civilians, the disruption of negotiations, and the collective punishment of Palestinians have got average ratios, that was consistent with the findings of (Hoffman, 2010), which stated that the US government has the ability to extend its influence on the media on foreign policy. The A media, and the government form certain frames, the fact that the US government in the end is the passage of most information ${ }^{(40)}$.

Israel, for its part, went too far in the policies of annexation and expansion, especially after President Donald Trump came to power. This is consistent with the study of (Hughes,2011), which stated that the establishment of the Palestinian Bantustans state is an Israeli interest to preserve the demographic balance in favor of the Jewishness of the state.

\subsection{Key Figures}

Table11: Key Figures of the Israeli settlement issue

\begin{tabular}{|c|c|c|c|c|c|c|c|}
\hline \multirow{2}{*}{\multicolumn{2}{|c|}{$\begin{array}{ll}\text { Website } & \text { Webures }\end{array}$}} & \multicolumn{2}{|l|}{ NT } & \multicolumn{2}{|l|}{ WP } & \multicolumn{2}{|c|}{ Total } \\
\hline & & \multicolumn{6}{|c|}{ Key Figures } \\
\hline \multirow[t]{2}{*}{ Israeli Key Figures } & Formal & 141 & 34.4 & 181 & 42 & 322 & 38.3 \\
\hline & Informal & 58 & 14.1 & 30 & 7 & 88 & 10.5 \\
\hline \multicolumn{2}{|l|}{ Total } & 199 & 48.5 & 211 & 49 & 410 & 48.8 \\
\hline \multirow[t]{2}{*}{ International Figures } & Formal & 105 & 25.6 & 152 & 35.3 & 257 & 30.6 \\
\hline & Informal & 29 & 7 & 9 & 2 & 38 & 4.5 \\
\hline \multicolumn{2}{|l|}{ Total } & 134 & 32.6 & 161 & 37.3 & 295 & 35.1 \\
\hline \multirow[t]{2}{*}{ Palestinian Figures } & Formal & 39 & 9.5 & 43 & 10 & 82 & 9.8 \\
\hline & Informal & 38 & 9.3 & 15 & 3.5 & 53 & 6.3 \\
\hline \multicolumn{2}{|l|}{ Total } & 77 & 18.8 & 58 & 13.5 & 135 & 16.1 \\
\hline \multicolumn{2}{|l|}{ Total } & 410 & 100 & 430 & 100 & 840 & 100 \\
\hline
\end{tabular}

The researchers consider that dominating the Israeli figures who spoke about Israeli settlement in the websites of the study is a clear bias in favor of Israel, and highlight the Israeli narrative at the expense of the Palestinian right. Despite the opposition of the international community to the settlement, the Palestinian figures were less visible in the websites of the study, this is a deliberate attempt to conceal the Palestinian narration.

The researchers conclude that intellectual orientations of the websites of the newspapers influenced the nature of the key figures that hosted in, this explains why Palestinian figures were in the last place, also this confirms the lack of official Palestinian figures who are good at talking to the international media, especially in an important issue such as the issue of Israeli settlement.

\footnotetext{
${ }^{39}$ Hughes, Territoriality, Sovereignty and the Nation-state System in Israel-Palestine: The Creation of the Palestinian Bantustan "state" and Shifting Palestinian Resistance Tactics.

${ }^{40}$ Hughes, Territoriality, Sovereignty and the Nation-state System in Israel-Palestine: The Creation of the Palestinian Bantustan "state" and Shifting Palestinian Resistance Tactics.
} 
This result is consistent with the results of Table (2) and Table (7), and this study is consistent with the study of (Issa, 2016), where the Israeli figures were the most hosted in the New York Times during the coverage of the 2014 aggression on the Gaza Strip, then the Palestinian \& International figures $^{(41)}$.

\subsection{Framing Mechanism}

Table12: Framing Mechanisms of Israeli settlement issue

\begin{tabular}{|l|l|l|l|l|l|l|}
\hline \multirow{2}{*}{ Framing mechanisms } & Website & NT & WP & \multicolumn{2}{l|}{ Total } \\
\cline { 2 - 7 } & $\mathbf{F}$ & $\mathbf{\%}$ & $\mathbf{F}$ & $\mathbf{\%}$ & $\mathbf{F}$ & \% \\
\hline Keywords & & & & & \\
\hline Quotations & 155 & 25.2 & 188 & 25.1 & 343 & 25.1 \\
\hline Previous news \& press releases & 156 & 25.4 & 185 & 24.8 & 341 & 25 \\
\hline Repetition & 133 & 21.7 & 185 & 24.8 & 318 & 23.3 \\
\hline Historical background \& information & 82 & 13.2 & 124 & 16.6 & 206 & 15.1 \\
\hline Drawingsand maps & 81 & 13.2 & 52 & 6.7 & 133 & 9.8 \\
\hline Total & 8 & 1.3 & 13 & 1.7 & 21 & 1.5 \\
\hline
\end{tabular}

The researchers conclude from receiving the Keywords the first place in the websites of the study the desire of the both websites to emphasize the contexts of the presented narrations, by preponderance the Israeli key figures on the Palestinian \& international key figures, and the fact that the Israeli humanitarian demonstrated on humanitarian concerns in the websites of the study, the website of the study used biased keywords in favor of the Israeli narration in reports that covered the issue of Israeli settlement, this study is consistent with the study of (Isa, 2016) where it showed that the New York Times used quotations with a high rate, $77 \%^{(42)}$, and this is also consistent the study of (Amer and Amer, 2011) where language analysis of the New York Times and The Washington Post showed that the vocabulary used in both newspapers when talking about Jerusalem is very close to the vocabulary used by Israelis ${ }^{(43)}$.

The high rate of quotations indicates attitudes of the websites of the study, the high rate of quotations besides the outnumbering of Israeli key figures on the Palestinian \& International key figures indicates the bias of the websites of the study to highlight the Israeli narrationat the expenses of the Palestinian

In the view of the researchers that the lack of use of drawings and maps in the websites of the study gives unreal impression to the reader about the form and the path of Israeli settlement. For example, the Washington Post relies on the facts omission which has great importance, the newspaper removes data that are detrimental to the justification of Israeli actions ${ }^{(44)}$.

\section{CONCLUSION}

- The volume of coverage of the Israeli settlement issue in the study sites was 365 news subjects, 175 news articles in the New York Times website and 190 news articles in the Washington Post site, which reflects the interest of the two websites to follow up settlement affairs, and convergence in the volume of interest between the two sites.

- The websites of the study relied on the reporter as being the only source in writing press reports on the issue of Israeli settlements, this indicates the interest of both websites to follow up the issue of Israeli settlement.

- The websites of the study used the report as the first place for the press forms of the Israeli settlement issue, with $88.3 \%$ in the New York Times and 95.3\% in the Washington Post.

- Although the main victim of the Israeli settlement issue is the Palestinians, the percentage of Palestinian humanitarian concerns in the two websites was weak, with $33.6 \%$ compared to $66 \%$ for Israeli humanitarian concerns.

\footnotetext{
${ }^{41}$ Issa, News frames of the Israeli aggression on Gaza 2014 in the website of the New York Times: an analytical study

${ }^{42}$ Ibid.

${ }^{43}$ Amer and Amer, U.S. Media Coverage of the Situation in Jerusalem: A Discourse Analysis Study.

${ }^{44} 110$ Examples of Post Misreporting. (Website)
} 
- The websites of U.S. newspapers focused on controlling the land as a main objective for supporting the settlements activity, this indicates the policy adopted by the Government of Israel against the Palestinians, and this is consistent with the results of those responsible for Israeli settlements in the study.

- The general tendency of the websites of U.S. newspapers was to hold the Israeli government responsible for the expansion of settlements. It was found that Netanyahu pursued a settlement policy in order to maintain the coalition government with the Israeli far right.

- The Israeli key figures have outnumbered the Palestinian \&International key figures in the websites of the study and this shows the weakness of the Palestinian presence in this vital Issue.

- The high percentage of words and quotes as tools to frame the issue of settlement indicates the bias of the websites of the study in favor of the Israeli side, as the area of quotations from Israeli figures is much larger than quotations from Palestinian figures, this result consistent the results of the key figures in the websites of the study.

- The issue of the Israeli settlement legality was the main topic in the websites of the study with $26 \%$, in line with the positions of successive US administrations and international positions rejecting it.

- The seizure of the Palestinian territories' frames has occupied the first place in the frames of the conflict in the Israeli settlement issue with $56.3 \%$, then the operations against settlers' -with $20 \%$, then checkpoints and arrests in front of Israeli settlements frames. This reflects the features of Israeli policy in the West Bank with the aim of creating a reality that does not allow any political entity for Palestinians.

- Balanced reactions came first among the responses to the Issue of Israeli settlement in the websites of the study with $52.3 \%$, then supported reactions with $29.5 \%$, and finally the opposition reactions with $18.1 \%$.

- The frames of the two-state solution received the highest percentage in the websites of the study, which indicates conducing it from the international community as asolution for the Israeli settlements issue.

- The confiscation of Palestinian land received the highest percentage of Israeli settlement results, reflecting the unpredictable future of the peace process between the Palestinian Authority and Israel.

- The expected results and responsibility frames received the highest percentage in the websites of the study, reflecting the impact of the Israeli settlements on the US-sponsored political process, as well as the clarity of the international position to the settlements activity and the responsibility of the Israeli occupation on this issue.

\section{REFERENCES}

[1] Al-Zahar, Reda. (2018) Stances of Opinion Articles in US online Newspapers in the Israeli Settlement in Palestine: A Comparative Analytical Study, (Unpublished Master Thesis), Islamic University, Gaza.

[2] Al-Ajla, Mohammad. (2015) Palestinian Discourse Towards the Israeli Settlement Issue in the West Bank: A Comparative Analytical Study, (Unpublished Master Thesis), Islamic University, Gaza.

[3] Al-Ajla, Rami. (2014) Discourse Towards the Issue of Jerusalem in International Arab Newspapers: A Comparative Analytical Study, (Unpublished Master Thesis), Islamic University, Gaza.

[4] .Qutob, Farah. (2009). An Analysis of Israel's Settlement Policy in the Occupied West Bank after the SixDay War and its Impact on the Peace-Process (1967-2002), Eastern Mediterranean University.

[5] Amer, Moshier and Amer, Walid. (2011). U.S. Media Coverage of the Situation in Jerusalem: A Discourse Analysis Study, Paper Presented at The $5^{\text {th }}$ Scientific Conference of the Faculty of Arts, Islamic University of Gaza, Gaza.

[6] Hughes, Sara. (2011). Territoriality, Sovereignty and the Nation-state System in Israel-Palestine: The Creation of the Palestinian Bantustan "state" and Shifting Palestinian Resistance Tactics, (Unpublished Master thesis) University of San Francisco.

[7] Arowolo, Sunday. (2017) Understanding Framing theory. Retrieved 19/09/2019from: https://bit.ly/2QbUeON 
[8] Entman, Robert, (1993) framing: Toward Clarification of Fractured Paradigm", Journal of Communication, 43(4), Washington: The International Communication Association.

[9] Eye on the post. 110 Examples of Post Misreporting. Retrieved December 27 ${ }^{\text {th }}, 2018$ from: http://www. eyeonthepost.org/110examples.html

[10] Amer, M. M. A. (2008). The linguistics of representation: the New York Times' discourse on the second Palestinian Intifada. PhD thesis, School of Languages and Linguistics, The University of Melbourne.

[11] Abadjiev, Nikolay. (2015). The return to Judea and Samaria: Qualitative analysis on the dynamics of Israeli settlements in West Bank and East Jerusalem, (Unpublished Master thesis) Webster University.

[12] Aljadba, Fawzi. (2005) Israeli Settlement in East Jerusalem 1967-2009: A Study in Geopolitics, Al-Aqsa University Journal, 5 (2), 98-125.

[13] A Aziz, Majdouline. (2007). An Analysis of Print Media Coverage of the Palestinian-Israeli Conflict During the Second Israeli Invasion of Lebanon in 2006, (Unpublished Master thesiss) Clemson University.

[14] Cornett III, Ward. (2008).Israeli West Bank Settlements: Perversion of Realism and Obstacle to Peace, (Unpublished Master thesis) Virginia Polytechnic Institute and State University.

[15] Hoffman, Jessica. (2010). Framing Hamas: A Case Study of U.S.

[16] Abuishaiba, Hani. The American Media Coverage of the Israel-Palestine Conflict (2010-2012). Research available on: https://goo.gl/wNWUEV

[17] Suzan Dente Ross, framing of the Palestinian Israeli conflict in thirteen months of New York times editorials surrounding the attack of September 11, 2001 - Analytical Study, conflict and communication online, 2(2), 2003. Web site: http://www.cco.regener-online.de/ 229

[18] Issa, Talat. (2016) News frames of the Israeli aggression on Gaza 2014 in the website of the New York Times: an analytical study, IUG Journal of humanities Research, Vol, 24. No. 1, Jan 2016, pp 144-174..

[19] Eglash, Ruth \& Hazaimeh, Hani. (19/03/2010) Why We Can't Write This Story. Retrieved December 27 ${ }^{\text {th }}$, 2018 from: https://bit.ly/2kRCael

[20] Abunimah, Ali. (18/09/2013). Washington Post's new Jerusalem correspondent married to pro-Israel propagandist. Retrieved December $27^{\text {th }}, 2018$ from: https://goo.gl/34TAzF

[21] Faqih, Mustafa. (February 24, 2014). Contemporary Arab Media, Retrieved on December 27, 2018 from: https://goo.gl/EZNquk

[22] Hadid, Dia. (April 17, 2015) Israeli Foreign Minister Denounces E.U. Proposal to Label Settlement Products. Retrieved December 27 ${ }^{\text {th }}, 2018$ from: https://nyti.ms/2moaY7p

[23] The Washington Post. (10/12/2015). Netanyahu wants Palestinian violence linked to radical Islam. Retrieved December $27^{\text {th }}, 2018$ from: https://goo.gl/v7W3y1

[24] Shaheen, Ahmed. (18/12/2015)The role of the media towards the Palestinian cause and mechanisms to promote global media solidarity with the Palestinian people, Retrieved on 27 December 2018 from: https://bit.ly/2HbLXSl

[25] The Washington Post. (18/01/2016). Palestinians attack inside settlements, Israeli mother of 6 killed. Retrieved December $27^{\text {th }}, 2018$ from: https://goo.gl/NR96DU

[26] The Washington Post. (18/12/2016). Trump once donated 10000\$ to a West Bank Israeli Settlement. Retrieved December $27^{\text {th }}, 2018$ from: https://goo.gl/TYGidy

[27] Edelstein, Alan. (05/11/2017). Isabel Kershner, the NY times and the demise of our democracy. Retrieved December $27^{\text {th }}$, 2018 from: https://goo.gl/xrLsva

Citation: Dr. Issa, Talat, Al Hamarna, Abdulla. "News Frames of Israeli Settlement in the American Newspapers' Websites". International Journal of Media, Journalism and Mass Communications (IJMJMC), vol 6, no. 1, 2020, pp. 01-12 doi: http://dx.doi.org/10.20431/2454-9479.0601001

Copyright: (C) 2020 Authors. This is an open-access article distributed under the terms of the Creative Commons Attribution License, which permits unrestricted use, distribution, and reproduction in any medium, provided the original author and source are credited. 